\title{
Feto-maternal outcome in pregnancies with preterm premature rupture of membranes: a tertiary hospital experience
}

\author{
Aparajita Sophia D'souza ${ }^{1}$, Moneet Walia ${ }^{1}$, Garima Gupta $^{1}$, Clarence Samuel $^{2}$, \\ Francis Sridhar Katumalla ${ }^{3}$, Sunitha Goyal ${ }^{1}$
}

\begin{abstract}
${ }^{1}$ Department of Obstetrics \& Gynaecology, Christian Medical College and Hospital, Ludhiana, Punjab
${ }^{3}$ Department of Community Medicine, Christian Medical College and Hospital, Ludhiana, Punjab

${ }^{2}$ Department of Urology, Christian Medical College and Hospital, Ludhiana, Punjab
\end{abstract}

Received: 02 September 2015

Accepted: 12 September 2015

\section{*Correspondence:}

Dr. Aparajita Sophia D’souza,

E-mail: dsouzaaparajita@yahoo.in

Copyright: (c) the author(s), publisher and licensee Medip Academy. This is an open-access article distributed under the terms of the Creative Commons Attribution Non-Commercial License, which permits unrestricted non-commercial use, distribution, and reproduction in any medium, provided the original work is properly cited.

\section{ABSTRACT}

Background: Preterm premature rupture of the membranes (PPROM) is a known dreaded complication of pregnancy as it is associated with significant perinatal complications. The objective of our study was to bring forward the incidence and feto-maternal outcome in pregnancies with PPROM in Indian scenario.

Methods: This retrospective cohort study was conducted in the Department of Obstetrics and Gynecology, in a tertiary hospital in Punjab between January 2014 and December 2014. Medical records of all pregnant patients who were admitted to our department with PPROM on the basis of clinical and /or laboratory data were reviewed. These 75 women were divided into two groups according to gestation age (GA), Group 1- early PPROM (24- 33 6/7 weeks of GA) (n=38) and Group 2- late PPROM (34-36 6/7 weeks of GA) (n=37). A multivariate analysis was used to find the association between PPROM and perinatal outcome.

Results: During the study period, there were 1528 deliveries in the hospital and 75 pregnant women were diagnosed to have PPROM giving an overall incidence of $4.9 \%$. In both the groups most common maternal complication was chorioamnionitis $(15.7 \%$ vs. $2.7 \%$ ) and most common neonatal complication was physiological jaundice (56.8\% vs. $69.2 \%$ ). Most of the babies required phototherapy (50\% vs. $43.5 \%$ ) and antibiotics. Our study demonstrated that patients in group 1 had significant increase in the frequency of chorioamnionitis, hyaline membrane disease, septicaemia, periventricular leukomalacia, intrauterine pneumonia, need for ventilator support and inotropes. Patients in group 2 had significant increase in the frequency of APGAR score $<7$ at $1 \mathrm{~min}$, APGAR $<7$ at 5 min and LSCS rate.

Conclusions: The study result implies that lesser the gestation age more are the chances of fetomaternal complications in patients with PPROM. Early PPROM is associated with higher rates of perinatal morbidity and mortality.

Keywords: PPROM, Chorioamnionitis, Feto-maternal outcome

\section{INTRODUCTION}

Preterm premature rupture of the membranes (PPROM) is a known dreaded complication of pregnancy as it is associated with significant perinatal complications. As per the definition, PPROM is the rupture of the amniotic membranes before 37 weeks' of gestation and before the onset of labour, while pre-viable PPROM occurs before 24 weeks' of gestation. ${ }^{1}$ One third of the preterm births are due to PPROM and it complicates about $3 \%$ of pregnancies. $^{2}$ 
PPROM is multifactorial in nature. Choriodecidual infection or inflammation is considered as a major etiology for PPROM, especially at early gestational ages.

3 Amniotic fluids have certain bacteriostatic properties that prevent infections and thereby prevent PPROM. Inline with this, oligohydroamnios is also considered responsible for PPROM. ${ }^{4}$ Deficiency of collagen content of the amniotic membranes is also among the other etiological factors of PPROM. ${ }^{5}$

Trauma, smoking, infections, low socioeconomic status, previous history of preterm delivery, sexually transmitted diseases, genetic and/or enzymatic abnormalities, nutritional deficiencies, incompetent cervix, placental abruption, procedures like amniocentesis and cerclage are known predisposing factors which may result in PPROM. $^{6-8}$

PPROM may cause perinatal complications like neonatal sepsis, respiratory distress syndrome, placental abruption, umbilical cord compression due to oligohydramnios and even carries a 1 to $2 \%$ risk of fetal death. ${ }^{9}$ Maternal complications like chorioamnionitis, premature delivery, and increased risk of caesarean section are also noted. ${ }^{6}$ Management of PPROM varies according to the gestational age of the fetus. Expectant management and immediate delivery are the two potential options of management in patients with PPROM with its advantages and disadvantages.

The objective of our study was to bring forward the incidence and perinatal outcome in Pregnancies with Preterm Premature Rupture of Membranes (PPROM) in Indian scenario.

\section{METHODS}

This is a retrospective cohort study conducted in the Department of Obstetrics and Gynecology, in a tertiary hospital in Punjab. We reviewed the medical records of all pregnant patients who were admitted to our department with PPROM on the basis of clinical and /or laboratory data from January 2014 through December 2014. The hospital database, including medical records, and labour ward and NICU registries were used to obtain the following information: 1) maternal demographics; 2) gestational age at PPROM and at admission; 3) use of antibiotics and corticosteroids for fetal lung maturity; 4) gestational age at birth and mode of delivery (vaginal or Caesarean section delivery); 5) presence of chorioamnionitis; and 6) maternal and neonatal outcomes. Gestational age was determined by asking the mother the date of her last menstrual period, if reliable, or by doing an ultrasound before 20 weeks gestation. Diagnosis of PPROM was based on history and vaginal examination. A history of sudden passage of amniotic fluid from the vagina or feeling wet with a pooling of amniotic fluid in the posterior fornix on sterile speculum examination or fern test confirmed the diagnosis. Finally, ultrasonography was done to assess the amniotic fluid index level. The patients were managed conservatively in the obstetrical ward and monitored for signs and symptoms of chorioamniotis or fetal compromise. All patients received oral antibiotics. The diagnosis of clinical chorioamnionitis was based on the presence of maternal pyrexia $\left(37.8^{\circ} \mathrm{C}\right.$ or $\left.100.4 \mathrm{~F}\right)$ and two or more of the following: maternal tachycardia $>100 \mathrm{bpm}$, fetal tachycardia $>160 \mathrm{bpm}$, uterine tenderness, purulent vaginal discharge, leucocytosis $>15,000$ or C-reactive protein $>2.7 \mathrm{mg} / \mathrm{dl}$. Indications for delivery included clinical chorioamnionitis, fetal death, or advanced labour. Viability was defined as a gestational age of 24 weeks and above, or an estimated fetal weight of 500 gram or above.

The study population consisted of 75 pregnant women who were admitted to our department with PPROM. These 75 women were divided into two groups according to gestation age, Group $1(n=38)$ - early PPROM (24- 33 $6 / 7$ weeks of GA) and Group $2(n=37)$ - late PPROM (34-36 6/7 weeks of GA).

A multivariate analysis was used to find the association between PPROM and feto-maternal outcome. Microsoft Excel (Microsoft, Redmond, Washington, USA) and the Statistical Package for the Social Sciences (SPSS), Version 19 (IBM, Inc, Chicago, Illinois, USA) were used for data analysis. A P value of $<0.05$ was determined to be statistically significant.

\section{RESULTS}

Table 1: Demographic and obstetrical variables with PPROM.

\begin{tabular}{|c|c|c|c|}
\hline \multicolumn{2}{|l|}{ Variables } & $\begin{array}{l}\text { Group 1 } \\
(n=38)(\%)\end{array}$ & $\begin{array}{l}\text { Group } 2 \\
(n=37)(\%)\end{array}$ \\
\hline \multicolumn{2}{|l|}{$\begin{array}{l}\text { Maternal } \\
\text { Age }\end{array}$} & $26 \pm 3.68$ & $27.8 \pm 4.83$ \\
\hline \multicolumn{2}{|l|}{ Parity } & $1.58 \pm 0.68$ & $2 \pm 1.03$ \\
\hline \multirow{2}{*}{$\begin{array}{l}\text { Antenatal } \\
\text { visits }\end{array}$} & Booked & $17(44.7 \%)$ & $27(73 \%)$ \\
\hline & Unbooked & $21(55.3 \%)$ & $10(27 \%)$ \\
\hline \multirow{2}{*}{$\begin{array}{l}\text { Type of } \\
\text { pregnancy }\end{array}$} & Singleton & $32(84.2)$ & $35(94.5)$ \\
\hline & Twin & $06(15.7 \%)$ & $02(5.4 \%)$ \\
\hline \multirow{3}{*}{$\begin{array}{l}\text { Fetal } \\
\text { presentation }\end{array}$} & Cephalic & $30(78.9 \%)$ & $31(83.7 \%)$ \\
\hline & Breech & $08(21.0 \%)$ & $06(16.3 \%)$ \\
\hline & Shoulder & 00 & $03(8.1 \%)$ \\
\hline
\end{tabular}

During the study period, there were 1528 deliveries in the hospital and 75 pregnant women were diagnosed to have PPROM giving an overall incidence of $4.9 \% .38$ patients were included in group 1 and 37 patients were included in group 2. The two groups were similar with respect to maternal age and parity. The pregnancies included 67 $(89.33 \%)$ singletons and $8(1.07 \%)$ twins. PPROM was more commonly seen in younger age group 21-25 yrs. (44\%). The maximum number of women in the entire study group were primigravida $(45.33 \%)$ followed by second gravida $(30.67 \%)$. Most of these patients were of 
low income group $(62.7 \%)$. Three $(4 \%)$ pregnancies were conceived through assisted reproductive technology. The PPROM occurred at less than 34 weeks in $50.67 \%$ (38/75), and between 34 and 37 weeks in $49.33 \%(37 / 75)$ of the mothers. Most common fetal presentation at the time of admission was cephalic $30(78.9 \%)$ group 1 and $31(83.7 \%)$ group 2 respectively. The demographic characteristics of women with PPROM in our study are elaborated in Table 1.

Prophylactic antibiotics were administered to all the mothers. In addition, betamethasone was administered in $81.6 \%(31 / 38)$ of the mothers with early PPROM and $45.9 \%$ (17/37) of mothers with late PPROM. In our study $36.8 \%$ gave birth within 2-7 days of PPROM in group 1 and $44.7 \%$ delivered within $<18 \mathrm{hrs}$. In group 2 (Table 2), therefore there was lesser incidence of chorioamnionitis in group 2 as shown in Table 3.

Table 2: Latency from rupture of membrane.

\begin{tabular}{|lll|}
\multicolumn{1}{|c|}{} & $\begin{array}{c}\text { Group 1 } \\
(n=38)(\%)\end{array}$ & $\begin{array}{l}\text { Group 2 } \\
(n=37)(\%)\end{array}$ \\
\hline$<18$ hrs. & $07(18.4)$ & $17(44.7)$ \\
\hline$>18$ hrs-48 hrs. & $06(15.8)$ & $07(18.9)$ \\
\hline $2-7$ days & $14(36.8)$ & $09(24.3)$ \\
\hline$>7$ days & $11(28.9)$ & $04(10.8)$ \\
\hline
\end{tabular}

Table 3: Maternal morbidity.

\begin{tabular}{|lll|}
\hline Mode of delivery & $\begin{array}{l}\text { Group } 1 \\
(\mathrm{n}=38)(\%)\end{array}$ & $\begin{array}{l}\text { Group } 2 \\
(\mathrm{n}=37)(\%)\end{array}$ \\
\hline Vaginal & $31(81.6 \%)$ & $17(45.9 \%)$ \\
\hline LSCS & $07(18.4 \%)$ & $20(54.1 \%)$ \\
\hline Indication of LSCS & & \\
\hline Twin pregnancy & $02(5.2 \%)$ & 00 \\
\hline Breech presentation & $02(5.2 \%)$ & $03(8.1 \%)$ \\
\hline Prev LSCS & $02(5.2 \%)$ & $05(13.5 \%)$ \\
\hline $\begin{array}{l}\text { Non reassuring fetal } \\
\text { heart rate }\end{array}$ & $01(2.6 \%)$ & $05(13.5 \%)$ \\
\hline Transverse lie & 00 & $03(8.1 \%)$ \\
\hline On request & 00 & $04(10.8 \%)$ \\
\hline Maternal morbidity & & \\
\hline Chorioamnionitis & $06(15.7 \%)$ & $01(2.7 \%)$ \\
\hline Abruption & $01(2.6 \%)$ & 00 \\
\hline Retained placenta & $06(15.7 \%)$ & 00 \\
\hline Sepsis & $01(2.6 \%)$ & $02(5.4 \%)$ \\
\hline
\end{tabular}

Labor started spontaneously in $60.5 \%$ (23/38) of the mothers in group 1 and $8.7 \%(12 / 37)$ in group 2 . Pregnancy was terminated by induction in $21.1 \%(8 / 38)$ and cesarean section before onset of labor in $18.4 \%$ (7/38) in group 1 and $13.5 \%$ (5/37) and 54.1\% (20/37) in group 2 respectively. Previous caesarean sections and non-reassuring fetal heart were the main indications for caesarean sections in both the groups (Table 3). Chorioamnionitis was seen in $6(15.7 \%)$ and $1(2.7 \%)$ of mothers in group 1 and 2 respectively. It was the commonest maternal complication observed in our study and it was statistically significant $(\mathrm{p}=0.0125)$. More maternal complications were observed in early PPROM. There were no reported cases of maternal mortality or long term morbidity.

Table 4: Perinatal outcome.

\begin{tabular}{|c|c|c|c|c|}
\hline Outcome & $\begin{array}{l}\text { Group } 1 \\
n=44(\%)\end{array}$ & $\begin{array}{l}\text { Group } 2 \\
n=39(\%)\end{array}$ & $\begin{array}{l}\text { Chi- } \\
\text { square }\end{array}$ & $\begin{array}{l}\mathrm{p}- \\
\text { value }\end{array}$ \\
\hline Still birth & $02(4.5)$ & 00 & 1.816 & 0.139 \\
\hline Neonatal death & $04(9.0)$ & $01(2.5)$ & 1.556 & 0.129 \\
\hline $\begin{array}{l}\text { APGAR }<7 \text { at } 1 \\
\min \end{array}$ & $03(6.8)$ & $09(23.0)$ & 4.419 & 0.043 \\
\hline $\begin{array}{l}\text { APGAR }<7 \text { at } 5 \\
\text { min }\end{array}$ & $02(4.5)$ & $08(20.5)$ & 4.974 & 0.032 \\
\hline $\begin{array}{l}\text { Hyaline } \\
\text { membrane disease }\end{array}$ & $21(47.7)$ & $05(12.8)$ & 11.71 & 0.0006 \\
\hline Septicaemia & $06(13.6)$ & 00 & 4.878 & 0.009 \\
\hline $\begin{array}{l}\text { Physiological } \\
\text { jaundice }\end{array}$ & $25(56.8)$ & $27(69.2)$ & 1.361 & 0.127 \\
\hline Birth asphyxia & $08(18.1)$ & $04(10.2)$ & 1.05 & 0.164 \\
\hline Refractory Shock & $05(11.3)$ & $03(7.6)$ & 0.32 & 0.301 \\
\hline Anaemia & $01(2.2)$ & 00 & 5.123 & 0.478 \\
\hline Acidosis & $04(9.0)$ & $01(2.5)$ & 1.556 & 0.178 \\
\hline $\begin{array}{l}\text { Acute kidney } \\
\text { injury }\end{array}$ & $01(2.2)$ & $02(5.1)$ & 0.483 & 0.276 \\
\hline $\begin{array}{l}\text { Retinopathy of } \\
\text { prematurity }\end{array}$ & $01(2.2)$ & 00 & 5.123 & 0.206 \\
\hline $\begin{array}{l}\text { Periventricular } \\
\text { leukomalacia }\end{array}$ & $04(9.0)$ & 00 & 2.929 & 0.037 \\
\hline $\begin{array}{l}\text { Intrauterine } \\
\text { pneumonia }\end{array}$ & $06(13.6)$ & $01(2.5)$ & 3.282 & 0.021 \\
\hline $\begin{array}{l}\text { Microangiopathic } \\
\text { purpura }\end{array}$ & 00 & $01(2.5)$ & 5.123 & 0.207 \\
\hline
\end{tabular}

A total of 83 neonates, $46(55.4 \%)$ males and 37 (44.6\%) females, were born ( 8 being twin pregnancies). The mean birth weight of the neonates was $1659.94 \pm 462.34 \mathrm{gm}$ and $2361.86 \pm 402.29 \mathrm{gm}$ respectively. There were a total of 7 perinatal deaths out of the 83 births; 2 being stillbirths and 4 early neonatal deaths in group 1 . There was only 1 neonatal death in group 2. Prematurity was the most common reason for perinatal mortality. Our study demonstrated that babies born to mothers with early PPROM had statistically significant increase in the frequency of hyaline membrane disease, septicaemia, periventricular leukomalacia, intrauterine pneumonia, need for ventilatory support and inotropes. Babies born to mothers with late PPROM had significant increase in the frequency of APGAR score $<7$ at $1 \mathrm{~min}$, APGAR $<7$ at 5 min and LSCS rate. In both the groups most common 
complication was physiological jaundice and maximum babies required phototherapy and antibiotics (Table $4 \&$ 5).

Table 5: Neonatal interventions.

\begin{tabular}{|lllll|} 
& $\begin{array}{l}\text { Group 1 } \\
n=44(\%)\end{array}$ & $\begin{array}{l}\text { Group 2 } \\
n=39(\%)\end{array}$ & $\begin{array}{l}\text { Chi- } \\
\text { square }\end{array}$ & $\begin{array}{l}\text { p- } \\
\text { value }\end{array}$ \\
$\begin{array}{|lllll|}\text { NICU Adm } \\
>24 \text { Hrs. }\end{array}$ & $34(77.2)$ & $33(84.6)$ & 0.7163 & 0.208 \\
\hline $\begin{array}{l}\text { Ventilatory } \\
\text { support }\end{array}$ & $14(31.8)$ & $03(7.6)$ & 7.389 & 0.006 \\
\hline Surfactant & $17(38.6)$ & $04(10.2)$ & 8.811 & 0.003 \\
\hline Antibiotic & $26(59.0)$ & $20(51.2)$ & 0.5103 & 0.243 \\
\hline $\begin{array}{l}\text { Photo } \\
\text { therapy }\end{array}$ & $22(50)$ & $17(43.5)$ & 0.3411 & 0.289 \\
\hline $\begin{array}{l}\text { Blood } \\
\text { transfusion }\end{array}$ & $03(6.8)$ & $01(2.5)$ & 0.8157 & 0.214 \\
\hline Inotropes & $10(22.7)$ & $03(7.6)$ & 3.358 & 0.033 \\
\hline
\end{tabular}

\section{DISCUSSION}

PPROM complicates only 3\% of pregnancies but is associated with $40 \%$ of preterm deliveries ${ }^{2}$ and can result in significant neonatal morbidity and mortality. The overall incidence of PPROM (4.9\%) was high in our study; it's mainly because the institution was a tertiary referral centre, but is comparable to range of 3-8 \% as reported by Egrater et al. ${ }^{9}$

PPROM was more commonly seen in younger age group 21-25 yrs. (44\%). The maximum number of women in the entire study group were primigravida $(45.33 \%)$ followed by second gravida (30.67\%). Most of these patients were of low income group $(62.7 \%)$. These observations are consistent with studies by Doa FA et al and Joelle $\mathrm{M}$ et al Stuart et al reported that the incidence of preterm PROM rose with advancing maternal age. ${ }^{10-12}$ However, this study was not in agreement with this observation.

The rate of maternal morbidity of $22.6 \%$ reported in this study is high compared to previous study by Vermillion et al but is an agreement with that reported by Yoon et al Infection rate of 13.3 percent was noted in this study in the mothers both intrapartum and postpartum. ${ }^{13,14}$ In this study, there was increase in incidence of infection with increased latency period more than 1 week. It has been found that $50 \%$ of patients with PPROM will deliver within $24-48 \mathrm{~h}$ and $70-90 \%$ within a week as reported by Dagklis et al. ${ }^{15}$ In our study $80 \%$ of the neonates delivered within first week of rupture of membrane. This latency period is similar to a previously reported review by Garite et al where $75 \%$ of patients delivered within a week. $^{16}$

Caesarean section rate was $36 \%$ for this study. This is comparable to a rate of $32.0 \%$ reported in study by Tauassoli et al but higher than $14 \%$ reported by Tahir et al. ${ }^{17,18}$ Kayem et al. in his study showed that neonatal death was not associated with any particular mode of delivery. ${ }^{19}$ Hence in early preterm after counselling, the patients were kept for vaginal delivery which explains higher LSCS rates in group 2 of our study. Prospective study by Tauassoli $\mathrm{F}$ et al had $5 \%$ incidence of chorioamniotis which is close to present study. The risk of infection is significant following PPROM. ${ }^{17}$ In this study, infection was the most important complication of PPROM and similar observation was noted by Stuart and his colleagues. ${ }^{12}$

In our study the neonates delivered following early PPROM were at a significantly higher risk for a multitude of adverse outcomes during the neonatal period. Even the neonatal death rate was higher among those delivered following early PPROM compared with later PPROM $(13.6 \%$ vs. $2.5 \%)$. In this study, the incidence of neonatal complications is high but comparable to that documented by Elimian et al and Dexter et al. ${ }^{20,21}$ This high neonatal complication may be related more closely to the effects of premature birth and sophistication of New born special care unit .

The major limitation of this study was the restriction of the study population to a central referral hospital and a small sample size. Hence the findings of this study may not reflect the true situation in the general population and should be interpreted with caution. Despite the limitations, this study has provided baseline information on PPROM in our setup and is a stepping stone towards further research on PPROM among Indian women.

\section{CONCLUSIONS}

PPROM is a major complication of pregnancies and an important cause of perinatal morbidity and mortality. Several areas of controversies exist regarding the best medical approach or management of PROM remote from term. Currently, there is no effective way of preventing spontaneous rupture of fetal membranes. The management of pregnancies complicated with PPROM, is individualized, highly controversial and challenging. Management of PPROM varies according to the gestational age of the fetus. Expectant management and immediate delivery are the two potential options in these patients, and each has its own merit and demerits.

Funding: No funding sources

Conflict of interest: None declared

Ethical approval: The study was approved by the Institutional Ethics Committee

\section{REFERENCES}

1. Beckmann, Charles (2014). Obstetrics and Gynecology, 7e. Philadelphia: Wolters Kluwer Health/Lippincott Williams \& Wilkins. pp. Chapter 17: Premature Rupture of Membranes. 2014;169173. 
2. Meis PJ, Ernest JM, Moore ML. Causes of low birth weight births in public and private patients. Am J Obstet Gynecol. 1987;156:1165-8.

3. Borna S, Borna H, Khazardoost S, Hantoushzadeh S. Perinatal outcome in preterm premature rupture of membranes with Amniotic fluid index < 5 (AFI < 5). BMC Pregnancy Childbirth. 2004;4:15.

4. Vintzileos AM, Campbell WA, Nochimson DJ. Degree oligohydramnios and pregnancy outcome in patients with PROM. Obstet Gynecol. 1985;66:1627.

5. Stuart EL, Evans GS, Lin YS, Powers HJ. Reduced collagen and ascorbic acid concentrations and increased proteolytic susceptibility with prelabor fetal membrane rupture in women. Biol Reprod. 2005;72:230-5.

6. Riyami NA, Shezawi FA, Al-Ruheli L, Al-Dughaishi T, Al-Khabori M. Perinatal Outcome in Pregnancies with Extreme Preterm Premature Rupture of Membranes (Mid-Trimester PROM). Sultan Qaboos Univ Med J. 2013;13:51-6.

7. American College of Obstetricians and Gynecologists Premature rupture of membranes. Clinical management guidelines for obstetriciangynecologists. ACOG practice bulletin no. 1.Int J Gynaecol Obstet. 1998;63:75-84.

8. Bendon RW, Faye-Petersen O, Pavlova Z, Qureshi F, Mercer B, Miodovnik M, et al. Fetal membrane histology in preterm premature rupture of membranes: comparison to controls, and between antibiotic and placebo treatment. Pediatr Dev Pathol. 1999;2:552-8.

9. Egarter C, Leitich H, Karas H, Wieser F, Hussiein P, Kader A, et al. Antibiotic treatment in preterm premature rupture of membranes and neonatal morbidity: a metaanalysis. Am J Obstet Gynecol. 1996;174:589-97.

10. Faksh A, Wax JR, Lucas FL, Castina A, Pinette MG. Preterm premature rupture of membranes $\geq 32$ weeks' gestation: impact of revised practice guidelines. Am J Obstet Gynecol. 2011;205:340 e 1-340 e5.

11. Lieman JM, Brumfield CG, Carlo W, Ramsey PS. Preterm premature rupture of membranes: is there an optimal gestational age for delivery? Obstet Gynecol. 2005; 105:12-7.

12. Stuart EL, Evans GS, Lin YS, Powers HJ. Reduced collagen and ascorbic acid concentrations and increased proteolytic susceptibility with prelabor fetal membrane rupture in women. Biol Reprod. 2005;72:230-5.

13. Vermillion ST, Soper DE, Chasedunn-Roark J. Neonatal sepsis after betamethasone administration to patients with preterm premature rupture of membranes. Am J Obstet Gynecol. 1999;181:320-27.

14. Yoon BH, Kim YA, Romero R, Kim JC, Park KH, $\mathrm{Kim} \mathrm{MH}$, et al. Association of oligohydramnios in women with preterm premature rupture of membranes with an inflammatory response in fetal, amniotic and maternal compartments. Am J Obstet Gynecol. 1999;181:784-88.

15. Dagklis T, Stamatios P. Parameter's affecting latency period in PPROM cases: a 10-year experience of a single institution. Journal of maternal-fetal and neonatal medicine. 2013; 26:1455-58.

16. Garite TJ, Freeman RK: Chorioamnionitis in the preterm gestation. Obstet Gynecol. 1982;59:539.

17. Tauassoli F, Ghasemi M, Mohamadzade A, Sharifian J. Survey of pregnancy outcome in preterm premature rupture of membranes with amniotic fluid index $<5$ and $\geq 5$. Oman Med J. 2010;25:118-23.

18. Tahir, Aleem M, Aziz R. Incidence and outcome of preterm premature rupture of membranes. Pak J Med Sci. 2002; 18:26-32.

19. Kayem G, Baumann R, Goffinet F, Abiad SE, Ville Y, Cabrol D, et al. Early preterm breech delivery: is a policy of planned vaginal delivery associated with increased risk of neonatal death? Am J Obstet Gynecol. 2008;198:289.e1-289.e6.

20. Elimian A, Verma U, Beneck D, Cipriano R, Visintainer P, Tejani N. Histologic chorioamnionitis, antenatal steroids and perinatal outcomes. Obstet Gynecol. 2000;96:333-6.

21. Dexter SC, Pinar H, Malee MP, Hogan J, Carpenter MW, Vohr BR. Outcome of very low birth weight infants with histopathologic chorioamnionitis. Obstet Gynecol. 2000;96:172-7.

Cite this article as: D'souza AS, Walia M, Gupta G, Samuel CJ, Katumalla FS, Goyal S. Feto-maternal Outcome in Pregnancies with Preterm Premature Rupture of Membranes: a tertiary hospital experience. Int J Reprod Contracept Obstet Gynecol 2015;4:1529-33. 